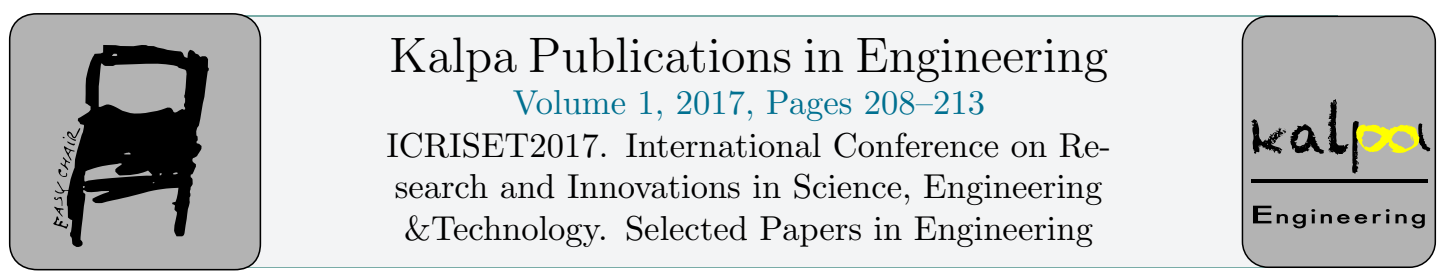

\title{
Simulation of Solar and Wind Power Plant Using MATLAB for Micro-Grid
}

\author{
Nisargkumar R Dave ${ }^{1}$ and Manish N Sinha ${ }^{2}$ \\ ${ }^{1}$ M.Tech (Electrical Engineering),B.V.M Engineering College, Vallabh Vidyanagar, India \\ ${ }_{2}^{2}$ Assistant Professor, B.V.M Engineering College, Vallabh Vidyanagar, India \\ ndisarg@yahoo.com, mns inha@bvmengineeringcollege.ac.in
}

\begin{abstract}
This paper includes modeling of Solar and Wind Plants of Micro-grid. Paper includes mathematical analysis, modeling of solar and wind source individual. And include modeling of simple P\&O MPPT method. The interconnection of the small-distributed generation such as PV, Wind turbine is connected to the common bus to supply load.
\end{abstract}

\section{Introduction}

In this paper, solar and wind plant is design for use of the common purposes and as one can utilize maximum power according to the Geo-graphical situation and can generate power and make a Micro-Grid (MG) for the local use for remote area like hill or tribal villages. The need of the energy is going to increases drastically in future years for which Micro-grid is a good solution for providing energy gap, which is not carried out by current fossil sources. Power generation community require to control it and use it optimally when required and also store extra power for future requirement, check islanding and grid connection mode of micro-grid as per criteria and requirement of the system. Micro-grid can play very important role in small scale distributed energy source utilization [1], so that wheeling cost of energy reduces. By use of renewable energy distribution generation, we can reduce cost for providing economical rate of energy for consumer. Fuel-Cell is also one emerging source in distributed generation also storage methods are little discussed in paper.

\section{Solar Power Plant}

In solar plant, main focus is generation of electrical energy, for that solar plant is simulated and modeled from equation. In simulation model as change in solar irradiance make different in solar array output. The change is in particular pattern, by understanding this pattern estimation of switching operation (from grid connection to islanded or islanded mode to grid connection) is easy. Design of Solar Plant include modeling of 1.)Solar Cell 2.)MPPT and Buck Converter 


\subsection{Solar Cell}

$$
\mathrm{I}=\mathrm{I}_{\mathrm{ph}}-\mathrm{I}_{\mathrm{s}}\left\{\mathrm{e}^{\mathrm{q}\left(\mathrm{v}+\mathrm{I}^{*} \mathrm{R}\right) / \mathrm{mKT}}-1\right\}-\left\{\left(\mathrm{v}+\mathrm{I}^{*} \mathrm{R}_{\mathrm{s}}\right) / \mathrm{R}_{\mathrm{L}}\right\}
$$

Characteristics equation is modeled into circuit form and Equivalent circuit is as fig.1 [2]

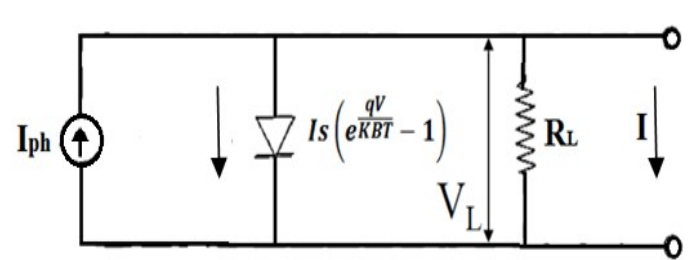

Figure1: Equivalent model of Solar cell [1]

Where, $\mathrm{I}_{\mathrm{ph}}=$ Photo-voltaic Current

Is = Saturation-current of the Diode

$\mathrm{q}=$ Electron charge in Coulombs $=1.602 * 10^{-19} \mathrm{C}$

$\mathrm{K}_{\mathrm{B}}=$ Boltzmann Constant $=1.380 * 10^{-23} \mathrm{~J} / \mathrm{K}$

$\mathrm{m}=$ Diode-ideality factor

Rs $=$ Series resistance

$\mathrm{R}_{\mathrm{L}}=$ Parallel resistance

$\mathrm{T}=$ Temperature in Kelvin

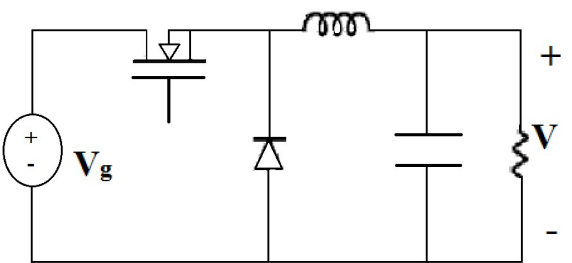

Figure 2: Basic Buck converter

$\mathrm{V}_{\mathrm{oc}}=$ Open-circuit Voltage

$\mathrm{I}_{\mathrm{pv} \_\mathrm{STC}}=$ Light generated current under STC (standard test Conditions)

$\Delta \mathrm{T}=(\mathrm{T}-\mathrm{Tstc})$ Kelvin

$\mathrm{G}=$ Surface irradiance of cell $\left(\mathrm{W} / \mathrm{m}^{2}\right)$

$\mathrm{G}_{\mathrm{STC}}=1000 \mathrm{~W} / \mathrm{m}$ (Irradiance under STC)

$\mathrm{Ki}=$ Short circuit current coefficient

$\mathrm{I}_{\mathrm{s} \_\mathrm{STC}}=$ Normal saturation current under STC

$\mathrm{T}_{\mathrm{STC}}=$ Temperature under STC

$\mathrm{E}_{\mathrm{g}} \quad$ = Ban-gap Energy of the Semiconductor

The array is formulated on following equation:

$\mathrm{I}=\mathrm{I}_{\mathrm{s}}\left(\mathrm{e}^{\mathrm{qV} /(\mathrm{KB} * \mathrm{~T})}-1\right)-\mathrm{I}_{\mathrm{ph}}$

$\mathrm{V}_{\mathrm{oc}}=\left(\mathrm{K}_{\mathrm{B}} \mathrm{T} / \mathrm{q}\right) * \ln \left[\left(\mathrm{I}_{\mathrm{ph}} / \mathrm{I}_{\mathrm{s}}\right)+1\right]$

The PV (photo voltaic) current $\mathrm{I}_{\mathrm{pv}}$ is a function of the irradiance $(\mathrm{G})$ and is formulated as:

$\mathrm{I}_{\mathrm{pv}}=\left[\mathrm{I}_{\mathrm{pv} \_ \text {stc }}+\mathrm{K}_{\mathrm{i}} \triangle \mathrm{T}\right] \mathrm{G} / \mathrm{G}_{\mathrm{stc}}$

Diode Saturation current $\left(\mathrm{I}_{\mathrm{s}}\right)$ is given in equation (5)

$\mathrm{I}_{\mathrm{s}}=\mathrm{I}_{\mathrm{s} \_\mathrm{stc}}\left(\mathrm{T} / \mathrm{T}_{\mathrm{stc}}\right)^{3} * \mathrm{e}^{(\mathrm{qEg} / \mathrm{MK})(1 / \mathrm{Tstc}-1 / \mathrm{T})}$

\subsection{MPPT and Buck Converter}

Conventional solar plant converts only 30 to 40 percent of the solar irradiance into electrical power. Maximum Power Point Tracking (MPPT) helps to improve the efficiency of solar panel. By maximum Power transfer theorem, the power output of circuit is maximum when the Thevenin impedance of the circuit matches with the load impedance. Due to this by matching impedance maximum power of solar panel is achieved. For matching impedance, buck converter is used to match source impedance with load impedance and also for enhancing the output voltage.

There are various MPPT methods like:

- Perturb and Observe (P\&O) (hill climbing method)

- Incremental Conductance method

- Fractional short circuit current

From the above-mentioned methods here Perturb and Observe (P\&O) method has been adopted to simulate solar MPPT due to it is simplest method and requirement of only voltage sensor for
- Fractional open circuit voltage

- Neural networks

- Fuzzy logic 
algorithm because of which it is very simple to implement and less time complexity. But it has certain disadvantages, in which it reaches near to MPP (Maximum Power Point) it doesn't stop it and continues to perturbate in both directions. And it is not accounting continuous change in irradiance. Working of the $\mathrm{P} \& \mathrm{O}$ is explained in fig.3.Here in $\mathrm{P} \& \mathrm{O}$ method first $\mathrm{V}$ and $\mathrm{I}$ is measured from plant, that power is measured and checked whether it increases or decreases. This indication is observed by power of the plant.

- If power of the array is increased, then $\mathrm{P} \& O$ checks whether voltage increases or decreases. If power is increased and voltage $\left(\mathrm{V}_{\mathrm{k}}\right)$ also increases, then voltage of the array should increase to get maximum power. And if voltage $\left(\mathrm{V}_{\mathrm{k}}\right)$ is decrease then array voltage should decrease.

- Now, if power is decreased, and voltage difference is also decreasing $\left(\mathrm{V}_{\mathrm{k}}\right)$ then array voltage should increase. But if voltage difference is increased then array voltage should decrease and after that value of measured voltage $\mathrm{V}_{\mathrm{k}}$ is updated to $\mathrm{V}_{(\mathrm{k}-1)}$ and power $\mathrm{P}_{\mathrm{k}}$ is updated in $\mathrm{P}_{(\mathrm{k}-1)}$.

- Buck converter, is one that converts high voltage to low voltage by switching a thyristor. Theoretical arrangement of the buck converter is as shown in fig. 2

- Here $\mathrm{V}_{\mathrm{g}}$ is solar array from that we are getting input and from converter we can convert that voltage into low level DC voltage. For method, we can use simple PWM method as comparing with the output, changes input. For that we can show simple method in fig.4

Buck converter, is one that converts high voltage to low voltage by switching a thyristor. Theoretical arrangement of the buck converter is as shown in fig.2. Here $\mathrm{V}_{\mathrm{g}}$ is solar array from that we are getting input and from converter we can convert that voltage into low level DC voltage. For method, we can use simple PWM method as comparing with the output, changes input. For that we can show simple method in fig.4. As indicated in fig.4 error amplifier (PI controller) is used to analyze error and after analyzing error, it generates control signal to maximize power.

\section{Wind Plant}

In wind turbine, power of wind is converted into electrical power that can be done by using various generators. In this case, we have used PMSG (permanent magnet synchronous generator) to convert wind power into electrical power and by using Buck converter, generated power is converted into DC power to make micro-grid a common DC Grid. The main advantage of the surface-mounted SG (synchronous generator) is its simplicity and low construction cost in comparison to the inset PMSG. However, the magnets are subject to centrifugal forces that can cause their detachment from the rotor and therefore the surface-mounted PMSGs are mainly used in low-speed applications. In a direct-driven WECS (wind energy conversion system), the synchronous generator with a high number of poles is used. The surface-mounted PMSG can have an external rotor in which the permanent magnets are attached to the inner surface of the rotor. In this case, the centrifugal forces help to keep the magnets attached to the rotor core.

$$
\begin{array}{ll}
\text { Kinetic energy } & \mathrm{KE}=1 / 2 * \mathrm{~m} * \mathrm{v}^{2} \\
& \mathrm{P}=1 / 2 * \mathrm{~m}^{*} \mathrm{v}^{2}
\end{array}
$$

Fluid mechanics gives mass flow rate

(Density * volume flux) $\mathrm{dm} / \mathrm{dt}=\rho * \mathrm{~A} * \mathrm{v}$

$$
\text { Total } \mathrm{P}=1 / 2 * \rho * A * \mathrm{v}^{3}
$$

Form this equation we can calculate input power of wind turbine. Here for simulation purpose MATLAB model of wind turbine with PMSG is used and after getting output from wind model, it is converted into DC so that power can be controlled easily and also stepped down to $200 \mathrm{~V}$ to match up the PV voltage level by Buck converter as shown in simulation \& result. 


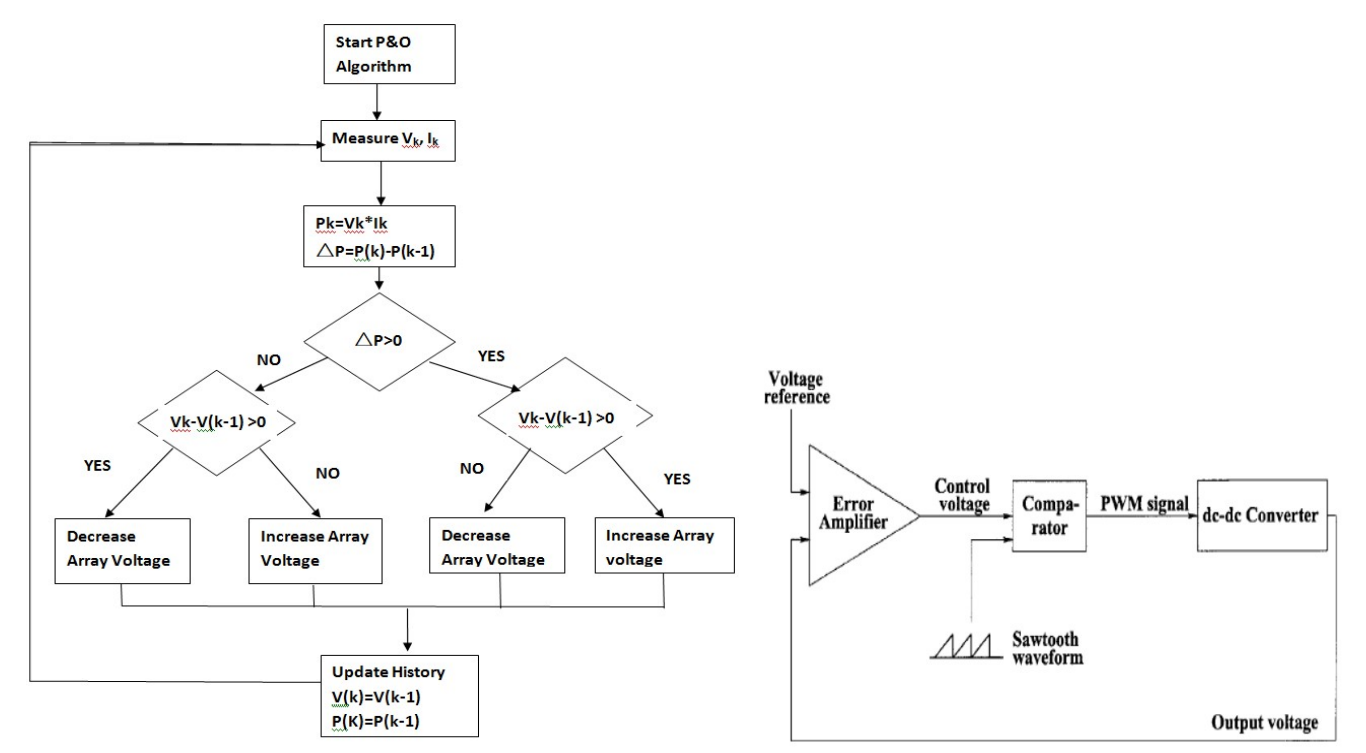

Figure 3: $P \& O$ Algorithm

Figure 4:Controlling of Buck-converter for $\mathrm{P} \& \mathrm{O}[3]$

\section{Fuel Cell and Storage System}

\subsection{Fuel Cell}

Fuel cell converts chemical energy into Electrical Energy directly through a chemical reaction. Fuel Cell is different as it requires continuous fuel. During operation, hydrogen-rich fuel and oxidant are separately supplies to the electrodes. Fuel is fed to the oxidant to the cathode and to streams is separated by electrolyte system. Heat and water are comes as byproducts

Hydrogen Fuel cell system has three major sub-system as:

1. Air supply by which pressure and flow rate are regulated and also for avoid oxygen starvation, excessive auxiliary power consumption

2. Fuel supply

3. Anode recirculation for reducing hydrogen waste, due to that pressure different between anode and cathode is minimized.

Fuel cell have several advantages over conventional generators due to high efficiency and low fuel oxidation temperature also fuel cell emits less $\mathrm{CO}_{2}$ and $\mathrm{NO}_{2}$ per kilowatt of power generation, there is no moving part so almost noise and vibration free. fuel cell require less maintenance. In fuel cell variety of fuels is possible like natural gas, propane, landfill gas, diesel, hydrogen.

\subsection{Storage system}

In Micro-Grid (MG) storage technologies is most important as MG cannot serve peak load and purchase power is expansive. Classification of storage systems are Mechanical, electrical, electrochemical, chemical, thermal etc. Storage system has certain advantage as:

1. It reduces electricity cost by storing electricity at off-peak time when its consumption is low for use at peak times.

2. It improve reliability of the power system.

3. It improves power quality, frequency and voltage. 


\section{Result and Simulation}

Here solar and wind plant is discussed. The solar power plant is modeled and simulated using mathematical equations, which are shown in fig.5. Here from PV array electrical energy is generated, that energy is supplied to MPPT for maximization. After that energy is supplied to simple resistive load. Results of Final voltage and current are shown in fig. 9 and 10 respectively. Simulation model of the solar cell according to equation (1), (2), (3) is formed as fig.6

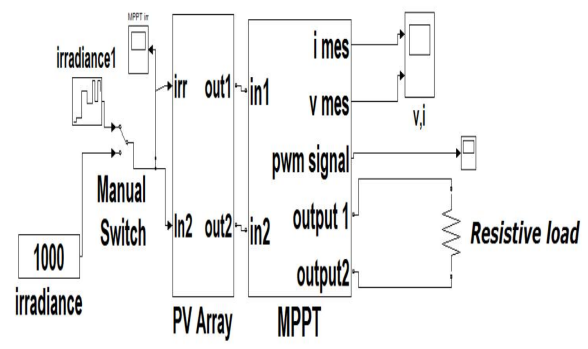

Figure 5: Solar plant overall layout

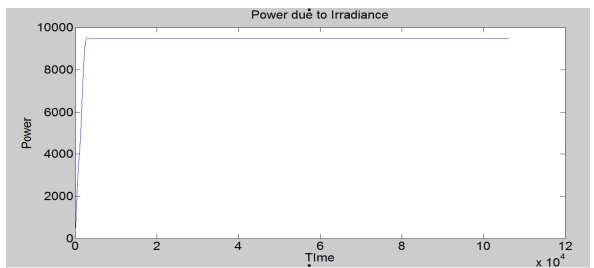

Figure 7: Power input due to Irradiance

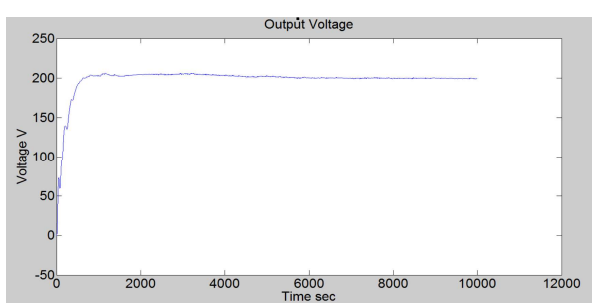

Figure 9: Output voltage of Solar Plant

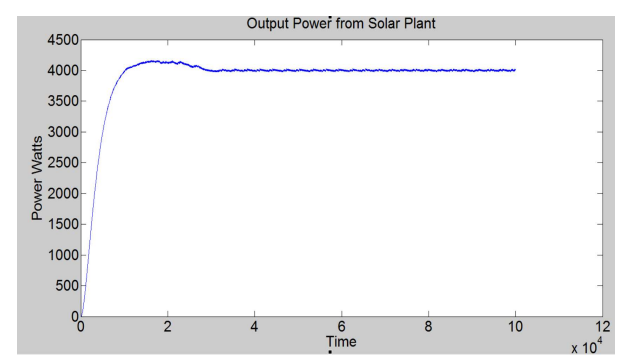

Figure 11: Output power from solar plant

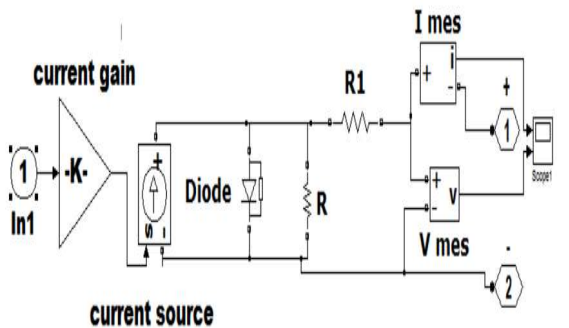

Figure 6: Solar cell simulation

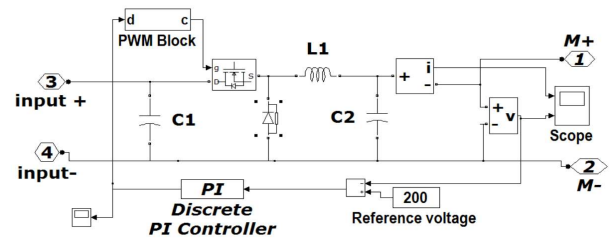

Figure 8: Buck converter with $\mathrm{P} \& \mathrm{O}$ algorithm

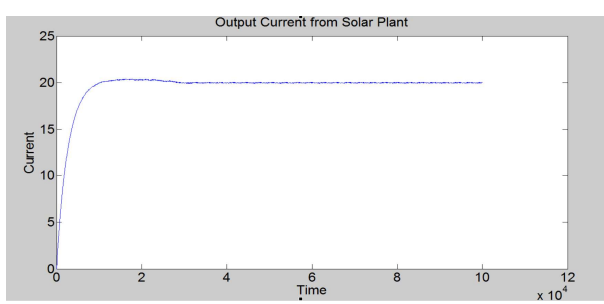

Figure 10: Output Current of Solar Plant

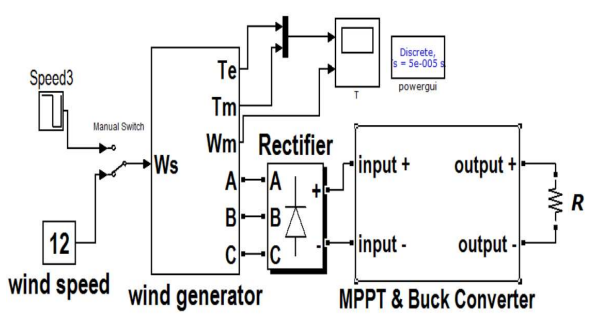

Figure 12: Overall Wind Simulation

\begin{tabular}{|c|c|}
\hline \multicolumn{2}{|c|}{ Data of Buck Converter } \\
\hline $\mathrm{C}_{1}=1.79 * 10^{-3} \mathrm{~F}$ & $\mathrm{C}_{2}=120^{*} 10^{-6} \mathrm{~F}$ \\
\hline $\mathrm{L}_{\mathrm{b}}=1.53 * 10^{-6} \mathrm{H}$ & $\mathrm{R}=125 \Omega$ \\
\hline Duty ratio $=0.125$ & $\mathrm{~F}=20^{*} 10^{3} \mathrm{~Hz}$ \\
\hline
\end{tabular}

Table 1: Data of Buck Converter 


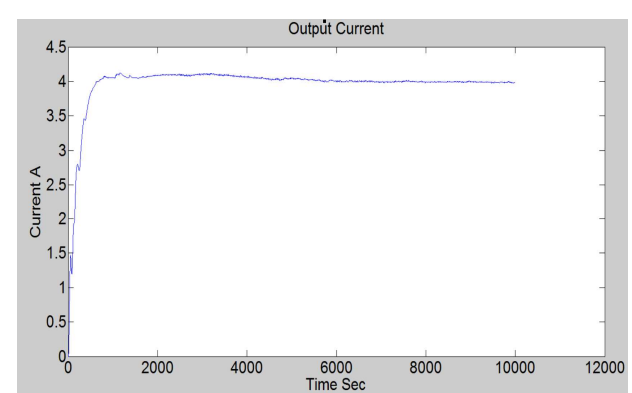

Figure 13: Output Current from Wind Plant

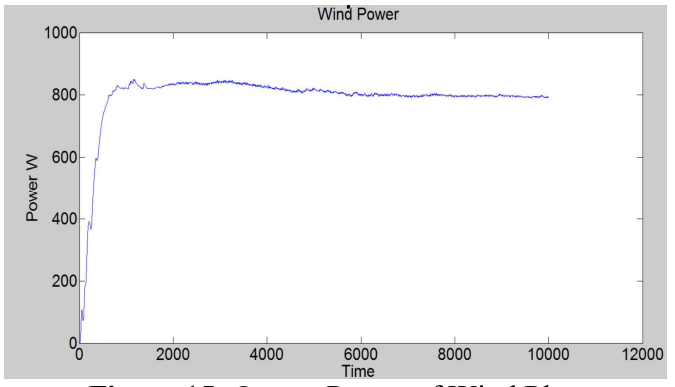

Figure 15: Output Power of Wind Plant

\begin{tabular}{|c|c|c|c|c|}
\hline \multicolumn{4}{|c|}{ Solar Plant } & \multirow{2}{*}{ Wind Plant } \\
\hline & Solar Array & \multicolumn{2}{|c|}{ Buck Converter } & \\
\hline Quantity & Output & Input & Output & Output \\
\hline V & $1600 \mathrm{~V}$ & $1600 \mathrm{~V}$ & $200 \mathrm{~V}$ & $200 \mathrm{~V}$ \\
\hline $\mathrm{I}$ & $2.5 \mathrm{~A}$ & $2.5 \mathrm{~A}$ & $19.4 \mathrm{~A}$ & $4 \mathrm{~A}$ \\
\hline $\mathrm{P}$ & $4000 \mathrm{~W}$ & $4000 \mathrm{~W}$ & $3880 \mathrm{~W}$ & $800 \mathrm{~W}$ \\
\hline \multicolumn{4}{|c|}{ Input Power from sun $=10000$ Watts } & Blade Length 9 Meter \\
\hline \multicolumn{4}{|c|}{ Over all plant Efficiency $(3880 / 10000)=38.8 \%$} & Wind Speed $12 \mathrm{~m} / \mathrm{s}$ \\
\hline
\end{tabular}

Table 2: Data of Solar \& Wind Plant

Input from the solar irradiance can be calculated as area of the solar at fix Irradiance of 1000 $\mathrm{W} / \mathrm{m}^{2}$. Simulation of Buck converter \& MPPT is shown in fig. 8 that shows when change in voltage is taken place, it changes input signal to PWM generator, which gives signal to thyristor to change output of the solar array. Here difference of signal is taken by PI controller. Values of all parameters are shown in Table-2. As shown in figure. 8 for making BUCK converter to convert voltage to $200 \mathrm{~V}$ for generating common DC bus the values of L, C and D are calculated as depicted in Table- 1 .

\section{Conclusion}

By modeling of the solar and wind plant, we get detailed idea about how these Distributed Generation sources change its generation according to solar irradiance and wind speed at STP. By modeling we can get idea about change in generation in different condition from, that we can determine whether system should operate in islanded or grid connected mode.

\section{References}

[1] P. Piagi, and R. H. Lasseter, “Autonomous Control of Microgrids”, IEEE PES Meeting, Montreal, June 2006

[2] N.Pogaku, M.Prodanovic, and T.C.Green ,"Modeling, Analysis and Testing of autonomous operation of an inverterBased Microgrid", IEEE Trans.Power Electronics,vol.22,pp.613-625,March 2007.

[3] Serban, and C.Marinescu, Roumaine das," Power Qulity Issues in a stand-alone microgrid based om renewable energy", Sciences Techniques.- Électrotechn. et Énerg., vol. 53(3), pp. 285-293, June- September 2008.

[4] F. Katiraei, and M.R. Iravani "Power Management Strategies for a Microgrid With Multiple Distributed Generation Units", IEEE Trans. Power Systems, vol. 21, no.4, pp. 1821-1831, November 2006.

[5] Ahmed M. Atallah, Almoataz Y. Abdelaziz, and Raihan S. Jumaah "Implementation of perturb and observe mppt of pv system with Direct control method using buck and buck-boost converters" Emerging Trends in Electrical, Electronics \& Instrumentation Engineering: An international Journal (EEIEJ), Vol. 1, No. 1, February 2014 